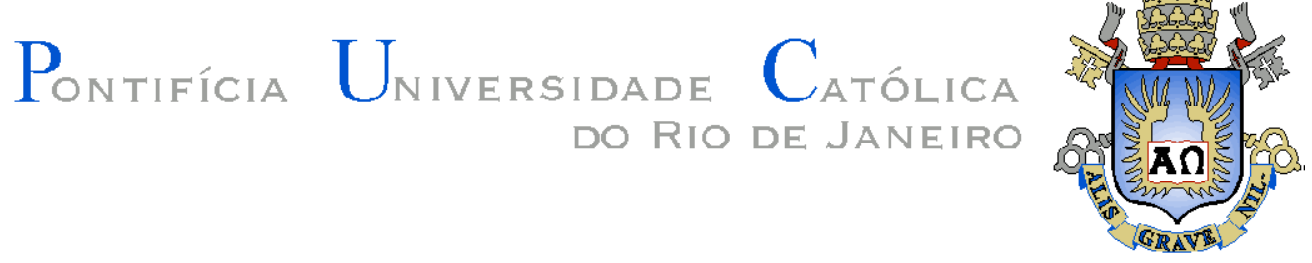

Paula Marchesini de Souza Mendes

\title{
A eternidade na obra de Jorge Luis Borges
}

\section{Dissertação de Mestrado}

Dissertação apresentada como requisito parcial para obtenção do título de Mestre pelo Programa de Pós-Graduação em Letras da PUC-Rio.

Orientador: Karl Erik Schöllhammer

Rio de Janeiro

Fevereiro de 2008 


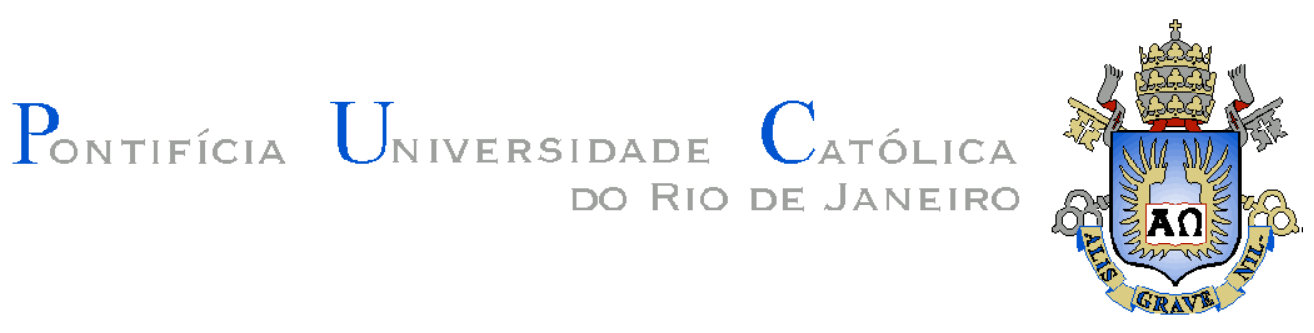

Paula Marchesini de Souza Mendes

\section{A eternidade na obra de Jorge Luis Borges}

Dissertação apresentada como requisito parcial para obtenção do título de Mestre pelo Programa de PósGraduação em Letras da PUC-Rio. Aprovada pela Comissão Examinadora abaixo assinada.

Prof. Karl Erik Schöllhammer Orientador Departamento de Letras - PUC-RJ

Prof. Paulo Fernando H. Britto Departamento de Letras - PUC-RJ

Prof. Mariluci da Cunha Guberman UFRJ

Prof. Paulo Fernando Carneiro de Andrade Coordenador(a) Setorial do Centro de Teologia e Ciências Humanas - PUC-Rio 
Todos os direitos reservados. É proibida a reprodução total ou parcial do trabalho sem autorização da universidade, da autora e do orientador.

\section{Paula Marchesini de Souza Mendes}

Graduou-se em filosofia na PUC-Rio, em 2005. Durante o curso de graduação, trabalhou especialmente com filosofia da linguagem, sobretudo com Ludwig Wittgenstein. Ao longo do mestrado em literatura, cursado também na PUCRio, trabalhou, especificamente, com a questão do tempo, analisando de que maneira esta se relaciona à criação artística.

Ficha Catalográfica

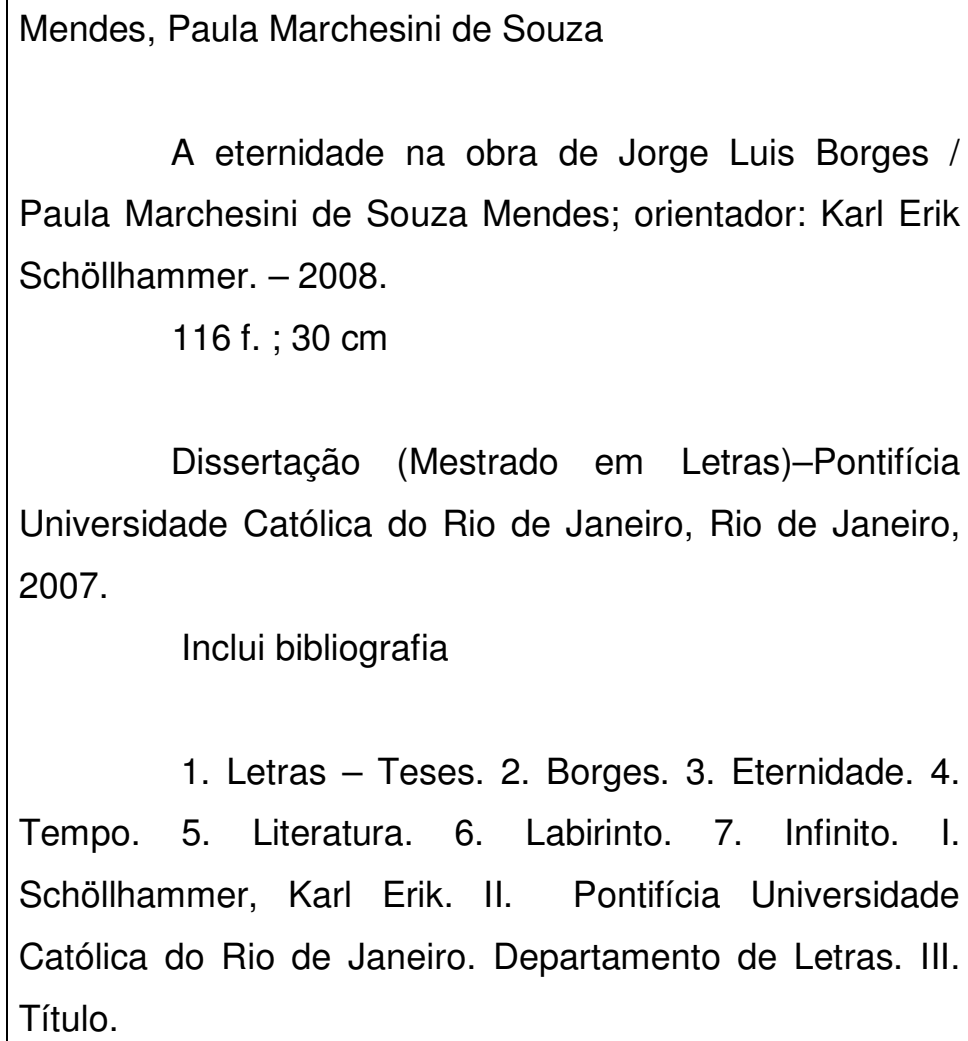
Schöllhammer, Karl Erik. II. Pontifícia Universidade Católica do Rio de Janeiro. Departamento de Letras. III. Título.

CDD: 800 


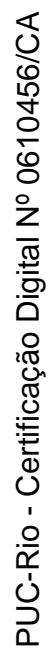

Para Apoena, por tudo. 


\section{Agradecimentos}

Ao meu pai, por todo o apoio e carinho, por ter me ensinado a pensar com clareza e por sempre me incentivar a crescer.

À minha mãe, por estar sempre pronta a me ajudar e por me inspirar, constantemente, com sua criatividade.

À minha avó, Olga Marchesini, por ter despertado meu interesse pela literatura.

A Karl Erik Shöllhammer, pela orientação impecável e pela paciência.

Aos membros da banca, Paulo Fernando H. Britto, pelas aulas inspiradoras e Mariluci da Cunha Guberman, pelas sugestões que tanto enriqueceram o trabalho e por ter me tratado de maneira tão carinhosa no dia da defesa.

À CAPES, pelo apoio financeiro, sem o qual a realização desse trabalho teria sido impossível.

Aos colegas da PUC-Rio.

A todos os professores do Programa de Pós-Graduação em Letras da PUC-Rio.

Ao departamento de letras da PUC-Rio, especialmente a Chiquinha, pelo carinho e profissionalismo. 


\section{Resumo}

Mendes, Paula M. S.; Schöllhammer, Karl Erik. A eternidade na obra de Jorge Luis Borges. PUC-RJ, 2008. 116p. Dissertação de Mestrado Departamento de Letras, Pontifícia Universidade Católica do Rio de Janeiro.

O presente trabalho analisa as figurações e o sentido do conceito de eternidade na obra de Jorge Luis Borges. No primeiro capítulo, destaca os principais símbolos borgianos atrelados ao conceito (a palavra, o nada, o eu, os animais, etc.); no segundo, as principais refutações do tempo, encontradas nos ensaios do autor; no terceiro e último capítulo, examina de que maneira o conceito de eternidade se vincula ao próprio fazer literário do escritor e à sua concepção de literatura. Tal análise quer proporcionar um novo enfoque sobre o trabalho do autor argentino, frizando, por trás de sua obsessão por labirintos, por enigmas e pelo problema do tempo, sua busca pelo centro, ou pela solução do enigma do tempo, vislumbrada, através da arte literária, no conceito de eternidade. Além disso, deseja analisar a relação ambígua que o autor mantinha com o conceito de eternidade, que via, ora como uma quimera que o homem deve abandonar para fazer parte do mundo, ora como um objetivo impossível que, somente através da literatura, pode ter algum significado para os homens.

\section{Palavras-chave}

Borges, eternidade, tempo, literatura, labirinto, infinito. 


\section{Abstract}

Mendes, Paula M. S.; Schöllhammer, Karl Erik. Eternity in the Works of Jorge Luis Borges. PUC-RJ, 2008. 116p. MSc. Dissertation Departamento de Letras, Pontifícia Universidade Católica do Rio de Janeiro.

The present document analyzes the figurations and the meaning of the concept of eternity in the work of Jorge Luis Borges. In the first chapter, it points out the main borgesian symbols linked to the concept (the word, the nothing, the I, the animals, etc.); in the second chapter, the main refutations of time, found in the author's essays; in the third and last chapter, it examines in what way the concept of eternity is related to the writer's process of literary creation and to his very concept of literature. Such analysis means to offer a new approach towards the argentine author's work, emphasizing, behind his obsession with labyrinths, enigmas and with the problem of time, his search for the center, or for the solution of the enigma of time, seen, through literary art, in the concept of eternity. Apart from that, it wishes to analyze the ambiguous relation the author maintained with the concept of eternity, seeing it at times as a dream that man should abandon to be part of the real world and, at other times, as an impossible goal that, only through literature, could have any meaning to men.

\section{Keywords}

Borges, Eternity, Time, Literature, Labyrinth, Infinity. 


\section{Sumário}

1. Introdução

2. Símbolos da eternidade

2.1. A palavra

2.2. O nada

2.3. A cegueira

2.4. O ponto, o círculo, o objeto

2.5. Os animais

2.6. O eu e a memória

2.7. Os arquétipos

3. Refutações do tempo

3.1. Paradoxos

3.2. O idealismo e a eternidade do instante

3.3. A impossibilidade do presente

4. Eternidade e literatura

4.1. A eternidade e a literatura como atividade impossível

4.2. A eternidade e a literatura fantástica

4.3. O Espírito ou o autor impessoal

4.4. O mundo como biblioteca ou livro 
Na eternidade, ao contrário, nada passa, tudo é presente, ao passo que o tempo nunca é todo presente. Esse tal verá que o passado é impelido pelo futuro e que todo ofuturo está precedido de um passado, e todo o passado e futuro são criados e dimanam d'Aquele que sempre é presente. Quem poderá prender o coração do homem, para que pare e veja como a eternidade imóvel determina o futuro e o passado, não sendo ela nem passado nem futuro? Poderá, porventura, a minha mão que escreve explicar isto? Poderá a atividade da minha língua conseguir pela palavra realizar empresa tão grandiosa?

Santo Agostinho, Confissões. 